\title{
Présentation du centre de documentation et de recherche sur la réalité gestuelle des sociétés humaines
}

Bernard Koechlin et Jean-Dominique Lajoux

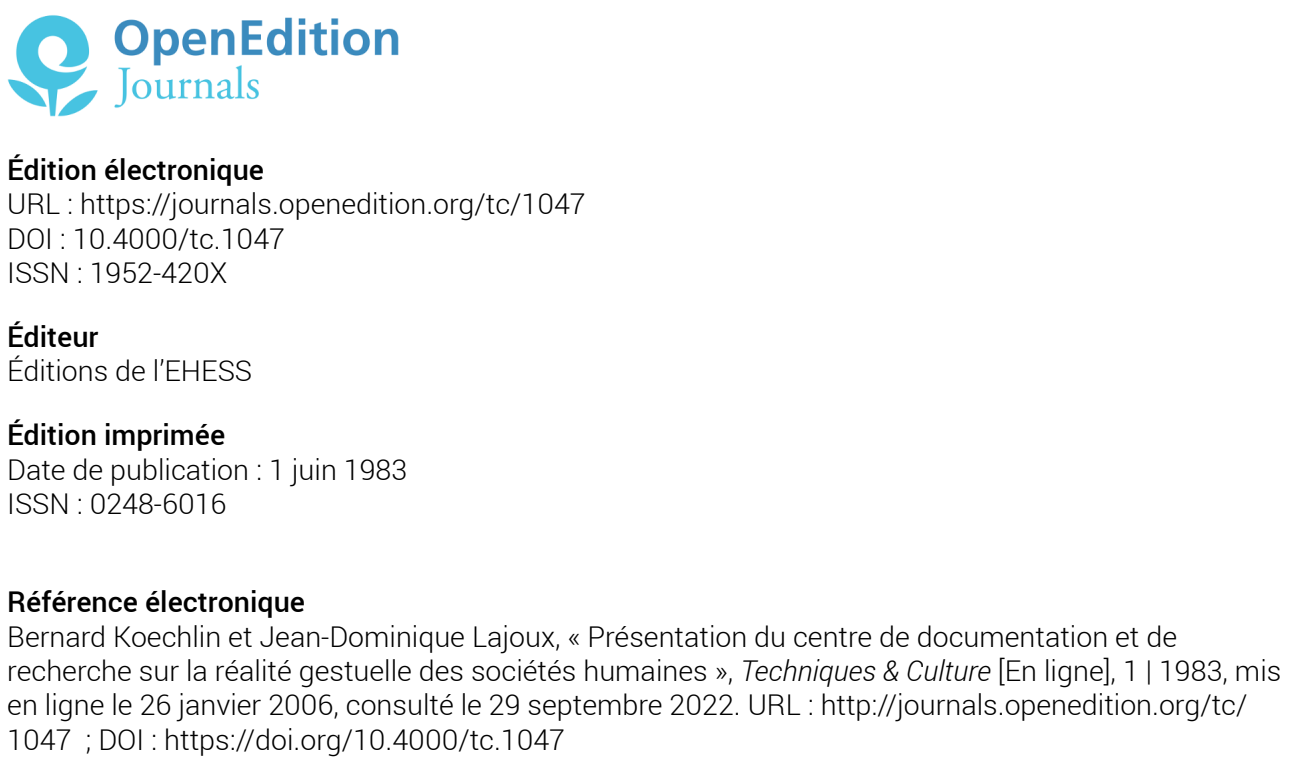

Ce document a été généré automatiquement le 29 septembre 2022.

Tous droits réservés 
Présentation du centre de documentation et de recherche sur la réalité gestuelle des sociétés humaines

Bernard Koechlin et Jean-Dominique Lajoux 